\title{
CSA och socialpolitiken kring sekelskiftet 1900
}

\author{
ROGER QVARSELL
}

\begin{abstract}
Fattigdom, bostadsbrist och sjuklighet var några av de sociala problem som utmärkte tiden kring sekelskiftet 1900. Genom bildandet av Centralförbundet för socialt arbete samlades tidens sociala reformivrare $i$ en gemensam strävan att utveckla det sociala arbetet och påverka den allmänna socialpolitiken.
\end{abstract}

När Centralförbundet för socialt arbete (CSA) bildades 1903 skedde detta i en situation när diskussionen om den så kallade sociala frågan var mycket intensiv. Hela sättet att se på fattigdomens orsaker, vad som kunde göras för att minska dess konsekvenser och vem som egentligen hade ansvaret för människors livssituation var stadd i förändring. Befolkningsökningen under 1800-talet, industrisamhällets förändrade relationer mellan arbetare och arbetsgivare och bristen på billiga bostäder i de växande städerna hade gjort fattigdomen mer synlig. Om antalet fattiga hade ökat låter sig inte avgöras på något enkelt

Roger Qvarsell, är idéhistoriker och professor vid den tvärvetenskapliga Institutionen för Tema vid Linköpings universitet. Han har i sin forskning främst behandlat medicin- och hälsohistoria, men även socialpolitikens och det sociala arbetets idéhistoria. sätt, eftersom det är svårt att jämföra människors levnadsförhållanden i tider av stora förändringar. Men vad som uppfattas som ett problem i samhället handlar lika mycket om hur frågan uppmärksammas och hanteras, som om de faktiska omständigheterna. Fattigvårdsförordningen från 1871 betonade det individuella och familjära försörjaransvaret och gav legitimitet åt en mer restriktiv kommunal fattigvård. Detta ledde bland annat till att såväl intresset som utrymmet för filantropiska insatser ökade vid denna tid, särskilt i de större städerna. Men problemen var stora och behovet av att finna mer rationella och effektiva metoder för att minska och helst förebygga nöden var stor. I bakgrunden fanns rädslan för att fattigdomen och det folkliga missnöjet kunde gynna radikala och revolutionära krafter. Försoning och samarbete mellan samhällsklasserna uppfattades som både 
mål och medel för den sociala reformverksamheten.

Sedan slutet av 1980-talet har en omfattande forskning ägnats det förra sekelskiftets sociala debatt och socialpolitiska reformer och många har betonat CSA:s betydelse som samlings- och mötesplats för dem som var engagerade i den sociala frågan. Men någon mer omfattande och samlad historisk skildring och analys av CSA:s tillkomst och verksamhet finns dessvärre ännu inte. Elsy Wennström vid idéhistoriska institutionen i Umeå arbetade i början av 1980-talet med en avhandling med denna inriktning, men hade dessvärre inte möjlighet att fullfölja arbetet. En opublicerad förstudie har haft stor betydelse för tillkomsten av den här artikeln (Wennström 1983). Förutsättningarna för en organisationshistorisk studie av CSA är dock mycket goda. Förbundets omfattande arkiv förvaras i Riksarkivet och innehåller protokoll, årsberättelser, publicerade skrifter, räkenskaper och dokumentation från olika konferenser och särskilda verksamhetsområden. Verksamheten kan även följas genom rapporter och artiklar i Social tidskrift och andra tidskrifter som rör sociala frågor, främst Svenska fattigvårdsförbundets tidskrift. Flera av de ledande personerna har också berättat om verksamheten i sina memoarer.

Även om en samlad framställning av CSA ännu saknas är mycket känt genom den nämnda forskningen om socialpolitikens historia kring sekelskiftet 1900. Betydligt svårare har det dock visat sig vara att finna rimliga sätt att skildra den idéhistoriska bakgrunden till och att karaktärisera de ideologiska positioner som utmärkte tidens socialpolitiska strävanden. Detsamma gäller försöken att värdera vilken betydelse CSA och sekelskiftets socialpolitiska debatt hade för utvecklingen inom det sociala området under mellan- och efterkrigstiden. Då dessa frågor kommer att beröras i den följande framställningen finns det därför anledning att understryka att forskningsläget är allt annat än glasklart.

Syftet med den här artikeln är inte att presentera ny empirisk forskning, utan att med utgångspunkt från vad som redan är känt försöka ge en historisk och idéhistorisk skildring av den socialpolitiska situationen kring det förra sekelskiftet. Framställningen kretsar kring några teman; hur man uppfattade de sociala problemen i det samtida samhället, relationen mellan den sociala debatten och mer grundläggande ideologiska ställningstaganden, sambandet mellan socialpolitik och socialvetenskap, samt vilken betydelse allt detta hade för den fortsatta utvecklingen inom det socialoch välfärdspolitiska området. Självfallet är detta allt för stora och komplicerade frågor för en kort artikel och framställningen måste därför få en essäistisk och tentativ karaktär.

\section{CSA och den sociala frågan}

Enligt en ofta berättad historia föddes tanken på ett förbund för att samordna olika organisationers strävanden inom det sociala området under en promenad på Djurgården sommaren 1902. De som promenerade var Gerda Meyersson och Gertrud af Klintberg och deras samtal ledde till att de under den kommande hösten kallade socialt intresserade i Stockholm till några möten. Året därpå bildades Cen- 
tralförbundet för socialt arbete med Ernst Beckman som ordförande, Agda Montelius som vice ordförande och Gerda Meyersson som sekreterare (Wirén 1980). Flertalet av dem som tidigt engagerade sig i CSA:s verksamhet var samtidigt verksamma inom någon annan organisation, som till exempel Föreningen för välgörenhetens ordnande eller Föreningen Studenter och arbetare. Några var även verksamma som skribenter och debattörer inom det sociala området och ytterligare några hade plats i riksdagen som representanter för de politiska partierna. Intrycket av CSA som samarbetsorganisation förstärktes när man hösten 1903 kunde etablera sig i ett hus som senare även kom att hysa andra organisationer inom det sociala området, till exempel Svenska Fattigvårdsförbundet och Folkbildningsförbundet.

Det är mycket möjligt att CSA kom till på så sätt att de personliga kontakterna mellan socialt verksamma och intresserade personer i huvudstaden utvecklades och organiserades. De berörda kretsarna av människor var ganska begränsade och alla kände i princip alla och hade mötts såväl $i$ arbetet med olika organisationer som i sällskapslivet. Statsvetaren Lennart Lundqvist har i boken Fattigvairdsfolket (1997) bekräftat denna bild genom att tala om nätverk av personer verksamma inom det sociala eller socialpolitiska området. I Per Erik Backs bok Sammanslutningarnas roll $i$ politiken som publicerades trettio år tidigare beskrivs dock CSA som en mer traditionell organisation inom det politiska området. Den förhållandevis lösa organisationsformen gör det även möjligt att jämföra CSA med vad som långt senare kommit att kallas för nya sociala rörelser, som just utmärks av att man lägger mer vikt vid själva verksamheten än vid former för medlemskap och beslutsfattande. Det förefaller rimligt att hävda att CSA fick sin betydelse i första hand genom att så många välkända och inflytelserika personer inom det sociala området valde att verka inom förbundet. Bland dessa kan kanske särskilt Agda Montelius, Ernst Beckman, Erik Palmstierna, Emilia Broomé, G. H. von Koch, Gerda Meyersson och Ebba Pauli nämnas. Den andra omständigheten som låg till grund för CSA:s inflytande inom det sociala området var utgivningen av Social tidskrift 1904-1917, samt en rad småskrifter inom skilda områden. För det tredje arrangerade man flera stora konferenser kring sociala frågor som dels fick stor uppmärksamhet i den samtida tidningspressen, dels besöktes av ett betydande antal kommunalt verksamma från olika håll i landet (Eklund 1928; Berge 1995; Edebalk 1996; Lundqvist 1997; Wästberg 2002).

Men om man skall ge en rimlig historisk bild av bakgrunden till det ökande intresset för socialpolitik och bildandet av en samarbetsorganisation åren efter sekelskiftet 1900 måste man naturligtvis också framhålla de betydande problem som fanns i samtiden, såväl på landsbygden som i de växande städerna och industriorterna. På landsbygden hade befolkningsökningen och försörjningsproblemen under det gångna seklet lett till en omfattande utvandring och en inflytning till städerna. Kvar fanns många gamla som försökte livnära sig på små gårdar med låg produktivitet och detta gällde framförallt de skogsbygder dit den nya jordbruksteknik som gradvis 
introducerades nådde förhållandevis sent. Genom att så många av de yngre och mest arbetsföra lämnade landsbygden ökade kommunernas kostnader för omhändertagandet av gamla och fattiga. För många kommunalt verksamma blev det därför naturligt att ställa krav på att staten skulle visa ett större intresse för de lokala försörjningsproblemen.

Den snabbt växande industrin sög till sig arbetskraften från landsbygden, men lönevillkoren var dåliga och trots långa arbetsdagar var det många som inte klarade sin försörjning. Bostadsbristen var stor, särskilt i Stockholm, och många tvingades bo trångt i usla lägenheter med barn, släktingar och inneboende i en salig blandning. Antalet ensamstående mödrar var betydande och detta skapade i sin tur problem för barnen som ibland lämnades utan tillsyn medan modern arbetade för deras gemensamma försörjning. Alkoholkonsumtionen var visserligen på tillbakagång, delvis som en följd av nykterhetsrörelsens massiva propaganda, men för många arbetarfamiljer var den ändå orsaken till att såväl ekonomin som sammanhållningen knakade betänkligt i fogarna.

I de flesta städer fanns en filantropisk hjälpverksamhet som syftade till att lindra nöden för de allra mest behövande och särskilt för dem som ansågs vara oskyldigt drabbade, så kallade rätta fattiga. Särskilda arbetarföreningar bildades, ofta med städernas ledande män i spetsen, som bland annat lanserade tanken på lokala försäkringssystem som skulle ge dem, som var tillräckligt skötsamma för att kunna spara en mindre summa, en viss trygghet $\mathrm{i}$ samband med sjukdom eller dödsfall. Även flera av de tidiga fackföreningarna organiserade försäkringskassor för sina medlemmar, liksom de försökte arrangera gemensamma utflykter och andra fritidssysslor för att hindra männen att gå till krogen och supa upp veckolönen (Taussi-Sjöberg \& Vammen 1995; Jordansson \& Vammen 1998; Plymoth 2002).

Många ansåg dock att dessa lokala insatser var otillräckliga och allt fler röster hördes i den sociala debatten med krav på en förändring av den statliga fattigvårdslagstiftningen. Med den lag som trädde i kraft 1871 hade man betonat familjemedlemmarnas ömsesidiga ansvar för varandra och givit mer restriktiva ramar för de lokala myndigheternas roll och ansvar när det gällde fattigvården. Upprördheten över den misär som fanns i städernas arbetarkvarter, oron över de långsiktiga konsekvenserna inte minst för barnen och känslan av ett gemensamt ansvar för samhällets utveckling förefaller att ha varit betydelsefulla drivkrafter för många av dem som verkade för sociala reformer (Berggren \& Nilsson 1965).

Sociologen Sven-Åke Lindgren har i flera arbeten diskuterat hur det kommer sig att vissa omständigheter $i$ bestämda situationer uppfattas som sociala problem som kräver någon form av politisk åtgärd eller lösning. Genom att inflytelserika grupper argumenterar för en viss fråga initieras en kollektiv definitionsprocess som gör denna till en gemensam angelägenhet och det går då att utkräva ansvar och kräva åtgärder. Problemet är då konstruerat i den meningen att dess sociala eller kollektiva karaktär främst är en följd av vilket genomslag denna definitionsprocess får i ett politiska eller publikt sammanhang (Lindgren 
1993). Från liknande utgångspunkter är det möjligt att diskutera de olika sätt på vilka man i historisk och samhällsvetenskaplig litteratur skildrat den tidiga socialpolitikens historia.

\section{Socialpolitiken i backspegeln}

Historisk och samhällsvetenskaplig forskning är alltid barn av sin tid och det vetenskapliga intresset för socialpolitikens historia kan i hög grad sägas spegla sentida förändringar i såväl den vetenskapliga som socialpolitiska debatten. Om man undantar enkla minnesskrifter började det vetenskapliga intresset för CSA med att sociologer och statsvetare med intresse för sociala rörelser och deras politiska inflytande uppmärksammade organisationens betydelse (Back 1967; Boalt \& Bergryd 1974; Boalt 1975). Flertalet arbeten om socialpolitikens historia betonade betydelsen av mellan- och efterkrigstidens omorientering av politiken mot generella välfärds- och inkomstutjämningsåtgärder och därmed socialdemokratins betydelse. I några arbeten framhölls betydelsen av en äldre och mer socialliberal tradition inom socialpolitiken, men det skulle dröja innan detta synsätt fick något större genomslag i den vetenskapliga och politiska diskussionen.

Först efter mitten av 1980-talet kan man i såväl svensk som internationell forskning inom området se en märkbar förändring i riktning mot att framhålla decennierna kring det förra sekelskiftet som en betydelsefull period i socialpolitikens historia. Därefter har en mycket omfattande forskning växt fram och som i sin tur ligger till grund för den här artikeln, som för övrigt inte hade kunnat skrivas för femton år sedan. Några orsaker till denna intresseförskjutning kan skisseras. För det första är det uppenbart att den omfattande kvinnooch genushistoriska forskningen har haft betydelse. Många av de föreningar som arbetade med sociala frågor i 1800-talets och sekelskiftets samhälle hade ett för sin tid mycket stort inslag av kvinnor, även på ledande poster. Särskilt i amerikansk forskning om det sociala arbetets historia har den filantropiska verksamheten framställts som ett förstadium till ett kvinnligt yrkesarbete inom det sociala området och därmed som ett inslag i en emancipationsprocess. För det andra speglar intresset den under 1980- och 1990-talen intensiva debatten om välfärdsstatens problem. Det politiska intresset för alternativ till en kostsam generell välfärdspolitik var betydande och dåvarande kristdemokratiske civilministerns beslut att tillsätta en utredning om så kallat frivilligt socialt arbete var ett av många tecken på detta. Vid samma tid började också röster höras som ifrågasatte prioriteringen av generella välfärdspolitiska åtgärder för att istället framhålla behoven av riktade insatser mot grupper som av olika skäl fallit igenom maskorna i det sociala skyddsnätet. Inte minst den omfattande massmediala uppmärksamheten kring de hem- eller bostadslösa i storstäderna gav betydande näring åt den diskussionen.

Det har ofta gjorts gällande att sekelskiften utmärks av att vissa grundläggande mänskliga villkor och samhälleliga förändringsprocesser ges en särskild uppmärksamhet. På samma sätt som varje nyår förefaller vara en tid för eftertanke på det individuella planet verkar sekelskiften har 
en motsvarande funktion i samhället. Att decennierna efter den franska revolutionen innebar stora förändringar när det gäller staternas engagemang inom social- och hälsopolitiken är väl dokumenterat. Sekelskiftet 1900 tillskrivs en liknande roll av många forskare inom området, och det finns kanske skäl att misstänka att åtminstone slutet av 1900-talet kommer att uppfattas som en tid av stora förändringar av framtidens historiker. Självfallet får den typen av historiska jämförelser inte drivas för långt, men det kan ha ett visst analytiskt värde att ställa olikartade samhällssituationer bredvid varandra för att bedöma såväl likheter som skillnader.

Ett problem i sammanhanget är att själva termen socialpolitik kan uppfattas som anakronistisk vid en skildring av den sociala diskussionen kring sekelskiftet 1900. Om man med socialpolitik menar direkta statliga åtgärder för att förändra sociala förhållanden så var det kanske snarare bristen på statlig politik som var det genomgående temat i den debatt som låg bakom tillkomsten av CSA. Men om man med socialpolitik menar debatten om sociala frågor, förslag till åtgärder för att lindra nöden och långsiktigt förebygga alla former av fattigdomen så var tiden kring det förra sekelskiftet en period av mycket intensiv socialpolitisk reformiver. Uppmärksamheten kring nationalekonomen Gustaf Cassels bok Socialpolitik från 1902 är ett exempel på socialpolitikens betydelse även i den allmänna politiska debatten. Men en grundläggande svårighet för alla som försökt att skildra denna socialpolitiska diskussion har varit hur den skall placeras in i samtidens politiska ideologier.

\section{Socialpolitisk ideologi}

Det har gjorts flera försök att ideologiskt karakterisera de socialpolitiska strävanden som fanns kring och inom CSA. Ingen av de etiketter som prövats har dock funnit ett stadigt fäste, vilket förmodligen till viss del beror på att de politiska ideologierna vid denna tid ännu inte var särskilt tydligt artikulerade. För många av dem som var verksamma inom CSA var det av stor vikt att framhålla att det inte fanns någon gemensam ideologisk eller religiös uppfattning, utan att man strävade efter, som man uttryckte det, samla alla goda krafter som var villiga att verka för sociala reformer (se tex Lundqvist, s 89). En sådan strävan efter konsensus och en tro på det goda sociala arbetets betydelse är naturligtvis också uttryck för en slags ideologi eller samhällsuppfattning.

Några gemensamma drag verkar dock finnas i den socialpolitiska ideologi som präglade den ledande gruppen inom organisationen. Att människor i så stor utsträckning som möjligt borde livnära sig och försörja sina familjer genom eget arbete var en självklar utgångspunkt. Kravet på självförsörjning kunde från konservativt håll ses som en moralisk plikt, medan liberalerna snarare resonerade om ekonomiska nödvändigheter. I den tidiga arbetarrörelsen var idealet om självförsörjning ett argument för att kräva högre löner så att en arbetare faktiskt skulle kunna försörja sin familj. En familj där mannen var arbetsam och nykter, hustrun skötte hemmet och hushållade med de knappa resurser som stod till buds så att man till och med kunde spara en slant inför ålderdomen framstod i många sammanhang 
som ett ideal. Även ett visst mått av nationalism och naturligtvis religiositet ingick i denna gemensamma idealbildning, bland annat för att man ville framhålla betydelsen av att ingå i ett större sammanhang (se bl. a. Hedin 2002).

Ett problem i den samtida debatten var att många uppfattade talet om det sociala eller den sociala frågan som uttryck för en socialistisk åskådning. I själva verket var nog tvärtom merparten av dem som förordade sociala reformer motståndare till det socialistiska kravet på en radikal utjämning av klasskillnaderna. Man strävade efter en ökad förståelse och samverkan mellan samhällsklasserna, men att det fanns skillnader mellan olika gruppers levnadssätt var inte bara naturligt utan också önskvärt. Inom arbetarrörelsen visade man också ett milt sagt måttligt intresse för den socialpolitiska debatten. Undantag fanns dock bland enskilda socialdemokrater, vilket kan ses som ett förebud om den kursändring i riktning mot social reformism som skulle ske under 1920-talet.

Till skillnad från socialisternas krav på en radikal samhällsomvandling anknöt flertalet sociala reformister kring sekelskiftet till den mer individuellt inriktade principen om hjälp till självhjälp. Innebörden av denna princip var att all hjälpverksamhet borde syfta till att ge den enskilde möjligheter att klara sig själv. För att detta skulle vara möjligt krävdes såväl rimliga löner som en moralisk fostran av arbetarna till nykterhet, skötsamhet och ansvarstagande. Självhjälpstanken hade sina ideologiska rötter i en individualistisk, liberal tradition, men användes flitigt också i mer konservativa kretsar. Att idén om självhjälp ingav för- hoppningar om möjliga framtida besparingar för fattigvården var säkerligen ett av skälen till dess popularitet. På ett retoriskt plan har talet om förebyggande åtgärder och därmed minskade kostnader alltid funnits med i diskussionen kring önskvärda sociala reformer. Ett annat skäl till självhjälpstankens betydelse var att den anknöt till en annan ideologisk grundföreställning, nämligen den om det individuella moraliska ansvaret för människorna som drabbats av svårigheter. Det är väl omvittnat att många av dem som deltog i det filantropiska arbetet drevs av eller rent av var besjälade av tanken på att de hade ett ansvar för andra. Om hjälpverksamheten uppfattades som en individuell relation mellan hjälparen och den behövande var det möjligt att uppnå resultat även med en begränsad insats och små resurser. En kristet inspirerad social idealism blev på det sättet en naturlig komponent i den ideologi som genomsyrade det sociala arbetet. Men det var också möjligt att förankra ett sådant ideal i mer naturfilosofiska resonemang, till exempel genom den i samtiden så populäre ryske författaren Peter Krapotkins tankar om inbördes hjälp. Krapotkin tänkte sig, i polemik mot socialdarwinisterna, att hjälpsamhet helt enkelt var ett naturligt tillstånd för såväl människor och djur och själva grundvalen för samhällsbildningen.

Kanske kan man tala om ett slags kluster av idéer i det som här lite konstruerat uppfattas som en gemensam socialpolitisk ideologi i kretsarna kring CSA. Ett individuellt ansvarstagande för andra, behovet av moralisk fostran av och ibland tvingande åtgärder mot de mindre skötsamma och en ökad samverkan och förståelse mellan 
samhällsklasserna var några av grundkomponenterna. Men även behovet av ökad samverkan mellan de filantropiskt verksamma och den kommunala fattigvården, önskvärdheten av förbättrad kunskap om sociala förhållanden genom olika former av utredningar och undersökningar, inrättandet av en statlig myndighet inom det sociala området och en förändrad lagstiftning var andra förekommande önskemål.

Men om allt detta kan sammanfattas i en enda ideologisk term är inte helt enkelt att avgöra. I litteraturen på området finns en rad olika förslag och mer eller mindre tydliga etiketteringar. Socialliberalism är kanske den term som oftast kommit till användning, men även socialreformism och liberalism förkommer (för exempel se Ohrlander 1992, Sjögren 1997; Thörn 1997, Hedin 2002). Om självhjälpstanken främst hör hemma $i$ en liberal tradition så bör kraven på moralisk fostran snarast uppfattas som uttryck för social- eller moralkonservatism. Att efterlysa ett ökat statligt engagemang $i$ samhällslivet var främst något som fanns $i$ allmänkonservativa kretsar, även om socialliberaler inte var främmande för tanken på en stark stat inom vissa specifika områden. Sekelskiftets socialpolitiska strävanden kan kanske sägas ha varit uttryck för en tidstypisk blandning av socialliberalism, socialkonservatism och kristen idealism.

\section{Vetenskapen och samhället}

Att decennierna kring sekelskiftet 1900 var något av en gyllene tidsålder för tron på vetenskapens möjligheter att förändra människors livsvillkor och världsbild har hävdats i många sammanhang. Den amerikanske idéhistorikern Franklin Baumer kallar i en lärobok de sista decennierna av 1800-talet rent av för en ny upplysningstid. Till skillnad från vad som var fallet under 1700-talet föreföll det dock som om medicinen och biologin var minst lika betydelsefulla som de rena naturvetenskaperna, inte minst när det gäller vetenskapens inflytande på hur man rent allmänt såg på människan och samhällslivet. De biologiska vetenskapernas inflytande på samhällsdebatten inskränkte sig dock inte till att ge underlag för en del ideologiska tolkningar av vetenskapen, som till exempel socialdarwinismen och rasbiologin. Mer genomgripande betydelse hade förmodligen strävan efter att sortera och klassificera, söka orsaker och behandlingsmöjligheter för olika typer av sociala förhållanden. Biologin och medicinen blev till en slags tankemodeller med en räckvidd långt utöver de egna kunskapsområdena, på samma sätt som fysiken och mekaniken hade varit det halvannat århundrade tidigare. De vetenskapsgrenar som i det sena 1800-talet studerade samhället och det sociala livet var åtminstone i teoretiskt avseende starkt beroende av dessa förebilder, samtidigt som man anknöt till den empiriska traditionen inom naturvetenskapen, med krav på noggrann kartläggning och utförlig dokumentation. Det skulle dröja innan socialvetenskapen fick en självklar plats inom universiteten, men de undersökningar och sociala kartläggningar som genomfördes av både myndigheter och filantropiska rörelser var i praktiken en form av vetenskaplig verksamhet (Beronius 1994; Eriksson \& Qvarsell 2000; Wisselgren 2000; Höjer 2001). 
Intresset för sociala undersökningar var på ett för den samtida samhällsvetenskapen utmärkande sätt på en gång vetenskapligt och politiskt motiverat. Genom att initiera och genomföra vetenskapliga studier av missförhållanden i samhället ansåg man sig ha en grund för att begära förändringar och nya insatser. Socialvetenskap och socialpolitisk argumentering gick hand i hand och någon egentlig eller tydlig gräns mellan dessa områden fanns inte. Den tidiga socialvetenskapen utmärktes också av att man i strävan efter att dokumentera och beskriva olika sociala förhållanden använde sig av flera olika hjälpmedel och genrer. Den mest välkända och kanske också viktigaste formen för social dokumentation var statistiken. Tanken att samhället kunde beskrivas med hjälp av siffror och tabeller hade sina rötter i 1700-talets merkantilistiska intresse för befolkningens sammansättning och försörjningsförmåga (Johannisson 1988). Men den statistiska metoden spred sig fram mot mitten av 1800-talet till en rad områden. Inte minst visade många läkare ett stort intresse för att tabellera såväl epidemiologiska förhållanden som kliniska behandlingsresultat. Det var knappast en tillfällighet att det var en läkare, pediatrikern Fredrik Theodor Berg, som blev den förste chefen för Statistiska centralbyrån. Med publicerandet av de omfattande serierna av offentlig statistik ökade självfallet kunskapen om olika samhällsförhållanden påtagligt, även om alla frågor som gällde sammanhang och förklaring överlämnades åt läsarna. I de större städerna inrättades i början av det nya seklet även lokala statistikkontor som tog fram uppgifter om en rad omständigheter som hade med de sociala livsvillkoren att göra. Även om det fanns en betydande osäkerhet kring hur sådana socialstatistiska undersökningar skulle genomföras spelade de en viktig roll, inte minst genom att sifferuppgifterna gav framställningen ett intryck av att vara genomarbetad. (Thörn 1997; Eriksson \& Qvarsell 2000). Minst lika stor betydelse för den socialpolitiska diskussionen var de mer etnografiskt inriktade studierna av sociala förhållanden. Några av de mer omfattande initierades och finansierades av den stiftelse för socialvetenskaplig forskning som tillkommit genom en donation av den framlidne Viktor Lorén. Genom stiftelsens skriftserie fanns möjlighet att få detaljerade inblickar i bostads-, avlöningsoch arbetsförhållanden såväl på landsbygden som i de växande industristäderna. I ett mer internationellt perspektiv spelade även den realistiska romanlitteraturen och intresset för socialt inriktad fotodokumentation en viktig roll för att förmedla kunskap om det liv som levdes i städernas fattigkvarter, under broar och på olika typer av tillfälliga härbärgen (Wisselgren 2000; Eriksson \& Qvarsell 2003).

Dokumentation av missförhållanden och argumentering för åtgärder var också givna beståndsdelar i all den verksamhet som fanns inom och kring CSA. I vissa fall förefaller det till och med ha varit så att man ansåg att det räckte med att beskriva människors livssituation, att något behövde göras borde vara uppenbart. Fattigvård, kriminalpolitik och hemlöshet var några av dessa frågor där man initierade verksamhet som hade betydande inslag av socialvetenskapligt inriktade undersökningar. 


\section{Det sociala ansvaret}

En grundläggande fråga $\mathrm{i}$ alla socialpolitiska debatter har varit vem som förväntas eller har en skyldighet att göra något och i så fall varför. De ständiga förskjutningarna av det sociala ansvaret mellan familj, lokalsamhälle, kyrka, kommun och stat speglar inte bara en önskan om att någon annan skall ta hand problemen och betala för åtgärderna, utan är även en följd av ideologiska ställningstaganden. Även det tidiga 1900-talets socialpolitiska diskussion och de förändringar som genomfördes kretsade i stor utsträckning kring frågor om ansvarsfördelning. Vid första påseende kan det måhända förefalla märkligt att framträdda företrädare för den filantropiska rörelsen bildade en samarbetsorganisation som bland annat verkade för att staten skulle ta ett större ansvar för olika sociala problem, ställa större krav på kommunernas fattigvård och bygga upp en central myndighet inom området. Men man måste då komma ihåg att den filantropiska rörelsen utvecklades snabbt under slutet av 1800-talet som en följd av att staten var förhållandevis passiv samtidigt som de sociala problemen blev allt mer påtagliga. Under 1910- och 1920-talen förändrades också den statliga politiken inom det sociala området på ett påtagligt sätt. En mer tydligt interventionistisk politik formerades och flera av de verksamheter som initierats av den filantropiska rörelsen övertogs och genomfördes av statsmakten (jfr. Killander 1991).

I den historiska litteraturen på området finns en viss oenighet om man skall se denna statliga inblandning i de sociala frågorna som tecken på att en ny syn på staten hade etablerats eller som en återgång till en äldre form av statspatriarkalism. Till viss del beror denna oenighet på att det inte är helt klart vad man skall mena med en statlig politik på det sociala området och på att man kan uppfatta staten på skilda sätt. Den polske historikern Bronislaw Geremek har talat om uppkomsten av en statlig socialpolitik redan på 1520-talet (Geremek 1991). För svenskt vidkommande skulle detta då kunna syfta på Gustav Vasas proklamation om att han som kung hade ett ansvar för dem som inte kunde försörja sig själva. Under de följande århundradena reglerades fattigvården på så sätt att man angav hur det sociala ansvaret skulle fördelas mellan husbönder, församlingar och statliga inrättningar. Det direkta statliga engagemanget gällde framförallt inrättandet av särskilda institutioner för grupper som inte ansågs kunna tas omhand i lokalsamhället. Sinnessjuka, föräldralösa barn, lemlästade soldater och veneriskt smittade hörde till dem som staten var beredd att sörja för. I övrigt handlade socialpolitiken om att ålägga andra att vidta åtgärder eller stå för kostnaderna för dem som inte kunde försörja sig själva. Som en följd av att antalet fattiga ökade och genom ett visst inflytande från manchesterliberala ideal betonades särskilt i 1871 års fattigvårdsförordning det individuella och familjebundna försörjningsansvaret, medan statens och kommunernas skyldigheter begränsades. I denna situation ökade såväl behovet av som utrymmet för frivilliga eller filantropiska insatser. Att dessa insatser uppfattades som otillräckliga var en av de främsta anledningarna till att CSA bildades och att den socialpolitiska debatten intensifierades i början av 
1900-talet. Det är därför kanske en öppen fråga om den nya socialpolitiken innebar att staten iklädde en ny roll eller om detta istället innebar slutet på en relativt kort period av låg statlig aktivitet på området. I vilket fall som helst var statens huvuduppgift även fortsättningsvis att fördela och organisera alla inblandade parters ansvar och skyldigheter. Den särskilda makt som tillkommer statsmakten innebar att man faktiskt kunde bestämma hur det sociala ansvaret i samhället skulle organiseras.

\section{CSA:s betydelse}

Avslutningsvis skall jag kort kommentera den inte helt enkla frågan om vilken betydelse CSA kan ha haft för den socialpolitiska utvecklingen i början av 1900-talet. Som organisation spelade CSA en mycket viktig roll inom hela det socialpolitiska fältet under seklets båda första decennier, men därefter har förbundets verksamhet och inflytande varit av mer blygsam natur. Men att en organisation får ett minskat inflytande kan tolkas på två helt olika sätt. Antingen beror det på att arbetet misslyckats och därför upphör att engagera eller så beror det på att man lyckats så väl med sina föresatser att organisationen inte längre behövs och de berörda kan ägna sig åt något annat. Det finns mycket som talar för att det är den senare tolkningen som är den rimliga i det här fallet.

Det är enkelt att ge exempel på att CSA faktiskt lyckades att förändra den statliga socialpolitiken och verksamheten inom det sociala området. Inrättandet av Socialstyrelsen 1912 och Socialdepartementet 1921 innebar att man fick till stånd en cen- tral samordning av de sociala frågorna på statlig nivå. Tillkomsten av Svenska stadsförbundet och Svenska landskommuners förbund fick stor betydelse för det lokala sociala arbetet och den utbildningsverksamhet som CSA initierade lade grunden för inrättandet av Socialpolitiska institutet i början av 1920-talet. Social Tidskrift, som spelade en mycket stor roll för den socialpolitiska debatten under ett decennium, lades visserligen ned 1917, men diskussionen fördes vidare i andra tidskrifter. Året därpå infördes en ny fattigvårdslag som tillgodosåg många av de krav som ställts inom organisationen och som man också hade haft ett betydande inflytande över. (Boalt \& Bergryd 1974, Olsson 1990, Bokholm 2000). Med en term lånad från Erik Blennbergers bidrag i den statliga utredningen Frivilligt socialt arbete från 1993 skulle CSA kunna karaktäriseras som en avantgardistisk organisation. Helt i linje med organisationens syfte initierade man en förändringsprocess, men överlät sedan merparten av genomförandet till andra. Till skillnad från vad som varit fallet med många andra liknande organisationer kan man inte spåra något intresse för att få organisationen i sig själv att överleva genom att omformulera dess mål eller förändra dess struktur. Tvärtom valde man att inta en mer passiv och betraktande roll inför den fortsatta socialpolitiska utvecklingen.

Kanske berodde denna hållning på att socialpolitikens förutsättningar förändrades under mellankrigstiden. Socialdemokratins ökade politiska inflytande och tydligare tonvikt på sociala reformer innebar en förändring av socialpolitikens innebörd. Den handlade inte längre om att hantera ett 
antal konkreta sociala problem, utan sågs som ett av flera instrument för att åstadkomma genomgripande förändringar av samhället. Visserligen var redan pensionsreformen 1913 ett steg i riktning mot generella välfärdspolitiska åtgärder, men det var först senare som den ideologiska innebörden av detta blev riktigt tydlig. I historieskrivningen inom det socialpolitiska området kan man fortfarande finna exempel på ganska schablonmässiga ställningstaganden till frågan om relationen mellan sekelskiftets socialpolitiska reformsträvanden och den utveckling som initierades under mellankrigstiden. Från socialliberalt håll betonas gärna inslagen av kontinuitet och betydelsen av pionjärinsatser, medan man från socialdemokratiska utgångspunkter hellre talar om ett ideologiskt brott mellan en gammaldags fattigvård och en modern välfärdspolitik. Även om det finns en omfattande historievetenskaplig litteratur om socialpolitikens historia är bilden av denna fortfarande till viss del ideologisk och måste kanske så vara. Intresset för historia handlar, enligt ett gammalt talesätt, om att söka sina rötter och bilden av komplexa historiska skeenden formas alltid i ett samspel mellan vad vi anser oss veta om det förflutna och våra försök att förstå vår egen tid.

\section{Litteratur}

Back, Per-Erik (1967) Sammanslutningarnas roll $i$ politiken. Lund: Studentlitteratur.

Berge, Anders (1995) Medborgarrätt och egenansvar. De sociala försäkringarna i Sverige 1901. 1935. Lund: Arkiv.

Berggren, Håkan \& Nilsson, Göran B. (1965) Liberal socialpolitik 1870-1910. Stockholm: Scandinavian University Books.

Beronius, Mats (1994) Bidrag till de sociala undersökningarnas historia eller till den vetenskapliggjorda moralens genealogi. Stehag: Symposion.

Boalt, Gunnar \& Bergryd, Ulla (1974) Centralförbundet för socialt arbete. Ett kapitel svensk socialpolitik. Karlskrona.

Boalt, Gunnar et al. (1975) De socialpolitiska centralförbunden. En jämförande studie. Karlskrona.

Bokholm, Sif (2000) En kvinnoröst i manssamhället. Agda Montelius 1850-1920. Stockholm: Stockholmia förlag.

Eklund, Oscar (1928) Centralförbundet för socialt arbete 1903-1928. Minnesskrift. Stockholm.

Edebalk, Per-Gunnar (1996) Välfärdsstaten träder fram. Svensk socialpolitik 1884-1955. Lund: Arkiv.

Erikson, Bengt Erik \& Qvarsell, Roger red. (2000) Samhällets linneaner. Kartläggning och förståelse i samhällsvetenskapernas historia. Stockholm: Carlssons.

Erikson, Bengt Erik \& Qvarsell, Roger red. (2003), "Samhället på bild. Den tidiga socialvetenskapen och det dokumentära fotografiet", Den ocensurerade verkligheten, red. Anna Meeuwisse \& Hans Swärd, f.c.

Geremek, Bronislaw (1991) Den europeiska fattigdomens betydelse. Stockholm: Ordfronts förlag.

Hedin, Marika (1998), "I det allmännas tjänst. Vetenskapen och socialpolitiken». Teknikens landskap, red. Marika Hedin \& Ulf Larsson. Stockholm: Atlantis.

Hedin, Marika (2002), Ett liberalt dilemma. Ernst Beckman, Emilia Broomé, GH von Koch och den 
sociala frågan 1880-1930, Eslöv: B. Östlings bokförl. Symposion.

Höjer, Henrik (2001), Svenska siffror. Nationell integration och integration genom statistik 1800-1870. Hedemora: Gidlunds.

Johannisson, Karin (1988), Det mätbara samhället.

Statistik och samhällsdröm i 1700-talets Europa, Stockholm: Norstedt.

Jordansson, Birgitta \& Vammen, Tinne ed. (1998), Charitable Women. Philantropic welfare 17801930. Odense.

Kilander, Svenbjörn (1991), Den nya staten och den gamla. En studie $i$ ideologisk förändring. Uppsala.

Lindgren, Sven-Åke (1993), Den hotfulla njutningen. Att etablera drogbruk som samhällsproblem 1890-1970, Stockholm/Stehag: Symposion graduale.

Lundqvist, Lennart (1997) Fattigvårdsfolket. Ett nätverk i den sociala frågan 1900-1920. Lund.

Ohrlander, Kajsa (1992) I barnens och nationens intresse. Socialliberal reformpolitik 1903-1930. Stockholm: Almqvist \& Wiksell International. Olsson, Sven E. (1990) Social Policy and the Welfare State in Sweden. Lund: Arkiv.

Plymoth, Birgitta (2002) Fostrande försörjning.
Fattigvård, filantropi och genus i fabriksstaden Norrköping 1872-1974. Stockholm: Historiska institutionen

Sjögren, Mikael (1997) Fattigvård och folkuppfostran. Liberal fattigvårdspolitik 1903-1918. Stockholm: Carlssons.

Taussi-Sjöberg, Marja \& Vammen, Tinne (1995) På tröskeln till välfärden. Stockholm.

Thörn, Kerstin (1997) En bostad för hemmet. Idéhistoriska studier i bostadsfrägan 1889-1929. Umeå: Institutionen för idéhistoria.

Wiklund, Doris red. (1989) FVO 100 år 18891989. Stockholm.

Wennström, Elsy (1983) „CSA - Idébakgrund och vetenskaper eller hjärtat och sifferkolonnerna». Opublicerat manus. Umeå: Institutionen för idéhistoria.

Wirén, Agnes (1980) G.H. von Koch. Banbrytare $i$ svensk socialvård. Ystad.

Wisselgren, Per (2000) Samhällets kartläggare. Lorénska stiftelsen, den sociala frågan och samhällsvetenskapernas formering 1830-1920. Stockholm: Symposion.

Wästberg, Per (2002), Axel Hirsch, Stockholm: Svenska Akademien.

\section{Summary}

\section{Social policy in Sweden at the beginning of the twentieth century}

During the last decades of the nineteenth century the political debate in Sweden, as in most other European countries, was focused on the growing social problems. Due to the ongoing transformation of the economic and social structure of society, the number of the poor and the unemployed was growing. The housing shortages in the cities increased the number of homeless people, and some of the health problems seem to have been caused by the lack of clean water and nutritious food. As the local poor relief was very restrictive, the work done by philanthropists was more and more important. In 1903 a group of influential philanthropists in Stockholm organized a society for social work (Centralförbundet för socialt arbete). One of the goals of the society was 
to induce the government to change the law on poor relief, another to intensify the public debate on various social problems. The society also organized conferences and courses for local social workers. All these efforts were to a large extent dependent on the improvement of scientific knowledge of the social conditions for the poor people. Supporting the early beginnings of the social sciences and initiating social investigations of different kinds of social problems was therefore important, not at least in order to convince the public of the necessity of social reforms. Historians are not in agreement about how to label the debate on social problems and social policy in relation to the contemporary ideological systems and ideas. The political ideas of the philanthropists seem to have been a mixture of liberalism and conservatism, but with a clear distance to socialism. Perhaps social reformers is the best of the suggested labels for the entire group of philanthropists, politicians, academic teachers and writers. Another question for historians has been the relation between the debate on social policy at the beginning of the nineteenth century and the establishment of the welfare state during the 1930s and especially the 1950s. 